\title{
Climatic differences and similarities between Indian and East Asian Monsoon regions of China over the last millennium: a perspective based mainly on stalagmite records
}

\author{
Ming $\operatorname{Tan}^{1}$
}

\begin{abstract}
:
Tan M. 2007. Climatic differences and similarities between Indian and East Asian Monsoon regions of China over the last millennium: a perspective based mainly on stalagmite records. International Journal of Speleology, 36 (2), 75-81 Bologna (Italy). ISSN 03926672

Cave sediments, especially stalagmites, have been providing absolute dated climate records that can extend from the present to over 500,000 years ago. Based on the reconstructed temperature time series, a comprehensive overview of the climatic differences and similarities between the Indian and the East Asian Monsoon regions of China over the last millennium is presented. Evidence from accurately dated and high-resolution records including stalagmites, ice cores and tree rings show that there was a "Medieval Warm Period" (around 1000 to 1400 AD) in north and east China where climate is dominated by the East Asian monsoon; whilst no such interval is evident in the records including stalagmites and ice cores from southwest China where climate is dominated by the Indian monsoon. However, both regions underwent a significant cooling during the Little Ice Age (around the mid 1500s to the 1800s). The result achieved here may allow a possibility of distinguishing the boundary between Indian monsoon and East Asian monsoon regions over the last millennium with increase of climate records, especially stalagmites that are mostly suitable for accurate U/Th dating and/or lamina counting.
\end{abstract}

Keywords: climate, China, stalagmite, ice core, tree ring, Medieval Warm Period, Little Ice Age, Indian monsoon, East Asian monsoon.

Received 12 April 2007; Revised 2 May 2007; Accepted 16 May 2007

\section{INTRODUCTION}

Climatologists have been paying great attention to the climate change in the last millennium (e.g. Jones et al., 1998; Mann et al., 1999; Briffa, 2000; Crowley \& Lowery, 2000; Esper et al., 2002; Mann \& Jones, 2003; Moberg et al., 2005) since the late 1990s for the evaluation of anthropogenic influence on climate. During the last millennium, the Medieval Warm Period (MWP, about 1000 to 1400 AD) is a distinct, centennial-scale climatic fluctuation presented firstly by Lamb (1965). Hughes \& Diaz (1994) indicated that the available evidence did not support a global MWP, although more support for such a phenomenon could be drawn from high-elevation records than from low-elevation records. According to Bradley et al. (2003), the warmest period prior to the Industrial Revolution over the last millennium did not appear at the same time in all regions. These overviews have led to much debate.

In China, Zhang (1993) indicated that the distribution

1 Research Fellow, Institute of Geology and Geophysics, Chinese Academy of Sciences, Beijing 100029, China

(E-mail: tanming@mail.iggcas.ac.cn) of some plants (ramie and orange) expanded to the north of the Huai River in central China in the mid 1300 's, and was in response to warmer conditions. Wang et al. (1998a) reconstructed 400-year or longer temperature records for 10 regions of China, showing that most regions underwent a cold period coinciding with the Little Ice Age (LIA; Lamb, 1977) over a wide-area of China. However, in some areas, such as southwest China, it is not entirely clear how the climate changed between 1000 to $1400 \mathrm{AD}$ due to a lack of accurately dated proxy time series.

High-precision and high-resolution dating is necessary for an effective discussion of climate change over the last millennium. Stalagmite/climate reconstruction work has made a notable contribution in paleoclimatic research in recent years by providing age-calibration for climatic events of the last glacial period (e.g. Wang et al., 2001) and strong support for the Milankovitch hypothesis (e.g. Yuan et al., 2004; Cruz et al., 2005). Besides the advantage of accurate dating using U/Th series via TIMS and/or ICP-MS methods (Li et al., 1989; Shen C., 2002), stalagmites have been used successfully to quantitatively reconstruct paleoclimate by lamina counting/ 
measuring (e.g. Procter et al., 2000; Tan et al., 2003; Frisia et al., 2003). However, many published stable isotope data from stalagmites have not been calibrated with meteorological data even though they were claimed to represent temperature or precipitation or monsoon. The work presented here attempts to interpret the signal of stalagmite oxygen isotopes from China by analyzing the relationship between regional precipitation and temperature as well as calibrating the proxy data with these observed data. With this result and other already published proxy records such as ice cores and tree rings, it is possible to evaluate the climatic differences and similarities between the Indian and East Asian Monsoon regions of China over the last millennium.

\section{DATA AND SETTINGS}

Changes in stalagmite oxygen isotope ratios during Holocene that are related to the Indian monsoon have been widely discussed (e.g., Neff et al., 2001; Fleitmann et al., 2003). The number of stalagmite oxygen isotope series from the Holocene of China that have been reported is increasing (e.g. Tan et al., 1998; Li et al., 1998; Hou et al., 2003; Paulsen et al., 2003; Zhang et al., 2004; Wang et al., 2005). In 2005, Tan $\&$ Cai compared the stalagmite oxygen isotope records from the Monsoon China (East to $108^{\circ} \mathrm{E}$ ), in which two questions were focused on:

1) what is the signature represented by the change in the stalagmite oxygen isotope records from Monsoon China within entire Holocene?

2) What is the range in values and the time series pattern for the stalagmite oxygen isotope ratios from Monsoon China?

Then subsequently, the authors compared four stalagmite oxygen isotope records (Fig. 1 \& 2):

(a) the stalagmite record from the Water Cave, Benxi, Liaoning Province $\left(41^{\circ} 17^{\prime} \mathrm{N}, 124^{\circ} 04^{\prime} \mathrm{E}\right)$. The oxygen isotope data of this stalagmite is approximately 5000 years long, from about $3000 \mathrm{BC}$ to 300 years before present and range from -8.2 to -9.5 (per mill $\mathrm{PDB}$ );

(b) The stalagmite record from the Shihua Cave, Beijing $\left(39^{\circ} 47^{\prime} \mathrm{N}, 11^{\circ} 56^{\prime} \mathrm{E}\right)$. The oxygen isotope data of this stalagmite has been reported by Hou et al. (2003). The record is approximately 2200 years long, from about $200 \mathrm{BC}$ to present. Oxygen isotope ratios range from -7.5 to -9.1 (per mill $\mathrm{PDB}$ );

(c) The stalagmite developed in the Dongge Cave, Libo, Guizhou Province $\left(25^{\circ} 17^{\prime} \mathrm{N}, 108^{\circ} 05^{\prime} \mathrm{E}\right)$. The oxygen isotope record of this stalagmite was reported by Wang et al. (2005). This record is approximately 9000 years long, from $6930 \mathrm{BC}$ to $2000 \mathrm{AD}$. The oxygen isotope ratios range from -6.64 to -9.14 (per mill PDB);

(d) The stalagmite developed in the Xiangshui Cave, Guanyang, Guangxi Province $\left(25^{\circ} 15^{\prime} \mathrm{N}, 110^{\circ} 55^{\prime} \mathrm{E}\right)$. The oxygen isotope record of this stalagmite was reported by Zhang et al. (2004). The record is approximately 6000 years long, from about 4000 BC to 500 years ago. The oxygen isotope ratios range from -5.6 to -6.5 (per mill PDB).

As shown in figure 2 , the oxygen isotope ratios become lighter from south to north. This pattern matches the observed pattern of summer monsoon. Starting from the south ocean and going northward, the summer monsoon supplies rainfall from the south to the north, and with precipitation oxygen isotope ratios become lighter known as "latitude effect" due to Rayleigh fractionation. This comparison of oxygen isotope ratios reveals that, in east China, stalagmite oxygen isotope records possess similar fluctuation patterns on millennial scale: all of them possess a multimillennial trend toward heavier ratios responding to a reduced insolation (Berger, 1978; Berger \& Loutre, 1991), similar to the record from Oman in the Indian monsoon area (Fleitmann et al., 2003).

\section{SIGNAL ANALYSIS}

The climate signal recorded in oxygen isotopes from stalagmites remains a problem although many theories or interpretations have been presented. Dansgaard (1964) once pointed out the effects of temperature, latitude, elevation and 'amount effect' on $\delta 180$ values of precipitation, however, the signature represented by changes in $\delta 180$ values of precipitation on decadal-centennial scales have been debated. Based on temperature-precipitation relationships on various temporal and spatial scales, the author here attempts to infer a large-scale temperature pattern from the stalagmite oxygen isotopes in monsoonal areas.

Firstly it should be recognized that the seasonal relationship between temperature and precipitation differs from the interannual one. In monsoon areas of China, temperature and precipitation have a positive relationship within a year because both are high in summer and low in winter. Using data from 1971 to $2000 \mathrm{AD}$ for Beijing as a case in point, the average monthly temperature has a high positive correlation with monthly precipitation ( $\mathrm{r}=0.98$, logarithmic relation, Fig.3). The "amount effect" drives the $\delta 180$ value of precipitation to more negative values in summer, corresponding to both high temperature and high precipitation in summer.

On the contrary, the correlation between interannual summer temperature and precipitation is negative $(\mathrm{r}=-0.39)$ for the same period because more rainfall results in cooler summer. Furthermore, the decadalscale variability or low-frequency signal shows a clearer negative relationship (Fig. 4). A similar relationship has also been shown by large-scale climate statistics. Dai et al. (1997) presented a combined yearly precipitation time series from 1900 to 1988 AD for the Northern Hemisphere $(\mathrm{NH})$, in which the trend of the combined precipitation profile is opposite to the average yearly temperature of the $\mathrm{NH}$ after $1935 \mathrm{AD}$ (Fig.5, temperature data from web site: http://www. cru.uea.ac.uk/cru/data/temperature/). Therefore, it is possible that:

1) the stalagmite oxygen isotope may be related to different climate signals at different temporal scales if it is affected by various meteorological factors;

2) long-term changes in stalagmite oxygen isotopes may represent only one kind of signal - temperature or precipitation. 


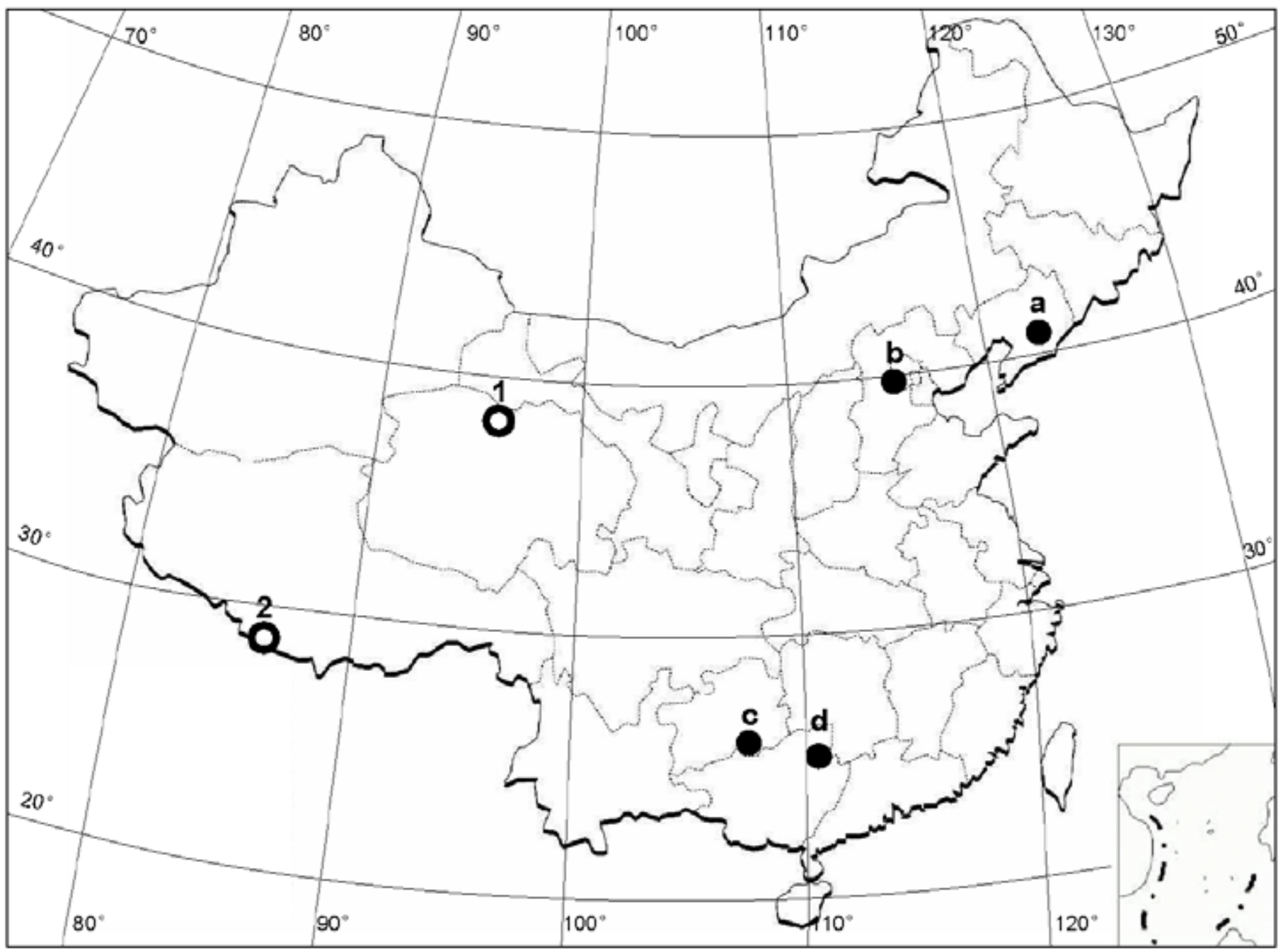

Fig. 1. Distribution of oxygen isotope records from stalagmites (dots, see text) and ice cores (circles, see text).

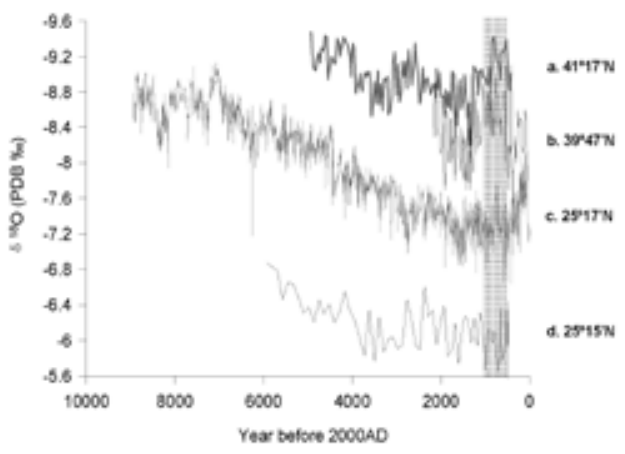

Fig. 2. Comparison of stalagmite oxygen isotope records from Water Cave (a) with that from Shihua Cave (b), Dongge Cave (c) and Xiangshui Cave (d). The shadow band covers the interval from about 1000 to $1400 \mathrm{AD}$, during which some regions are warm known as the MWP (see text).

To understand what the oxygen isotope time series mentioned in Fig.2 represent, the author once compared the record from Shihua Cave $(b$ in Fig.2), which has already been age-controlled by counting chronology, with large-scale quantitatively reconstructed proxy records (Moberg et al. 2005, Data from website: http://wdc.cricyt.edu.ar/paleo/

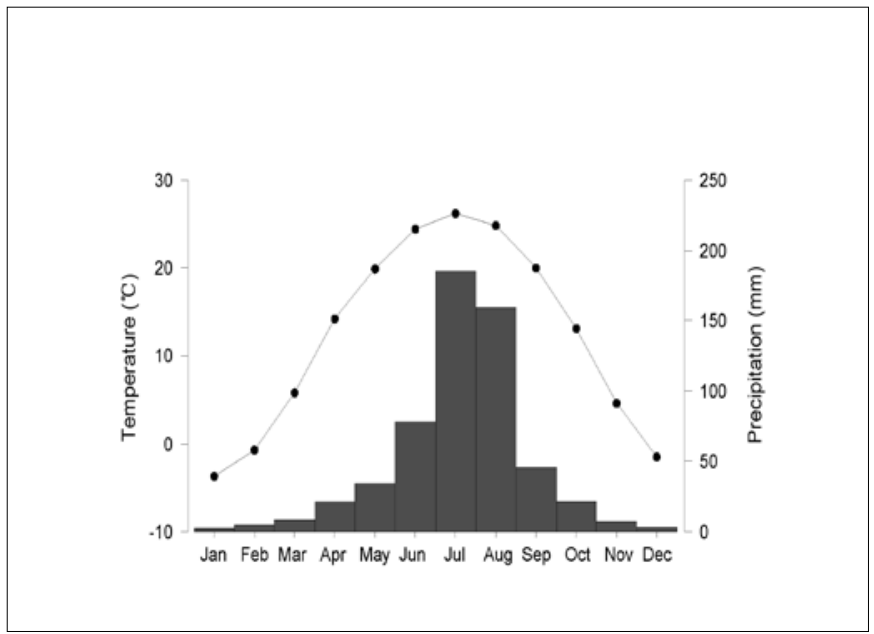

Fig. 3. Beijing monthly average temperature (line with dots) and precipitation (bars). There is a strong positive seasonal relationship between the two meteorological factors $(r=0.98$, data from 1971-2000 $A D)$.

data.html). It was found that the re-dated oxygen isotope series has a statistical significant relationship ( $\mathrm{r}=-0.35, \mathrm{n}=107, \mathrm{p}<0.001$ ) with the 2000-year long $\mathrm{NH}$ temperature series. This result shows that the lighter oxygen isotope ratios in the stalagmite from Beijing Shihua Cave correspond to higher temperatures (Fig. $6)$. Based on this comparison, it may be inferred that 


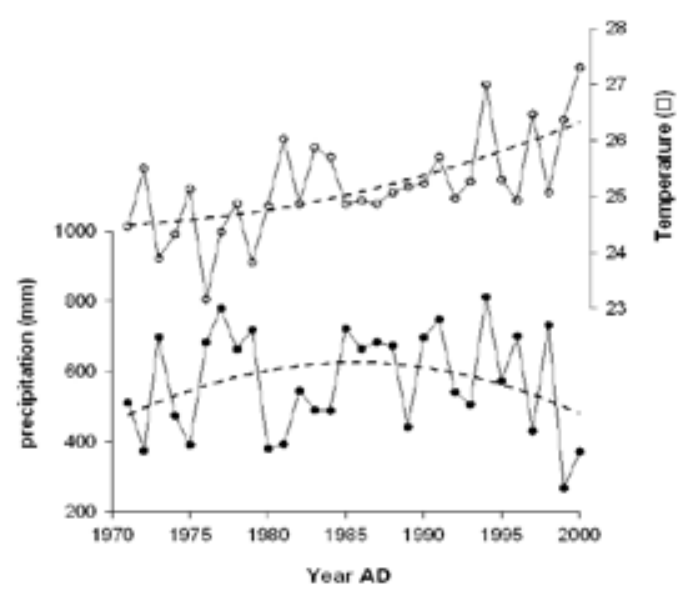

Fig. 4. Comparison of observed temperature (upper curve) and summer (JJA) precipitation (lower curve) in Beijing from 1971 to 2000 $A D$. The thick lines are 2 nd-order polynomial fits.

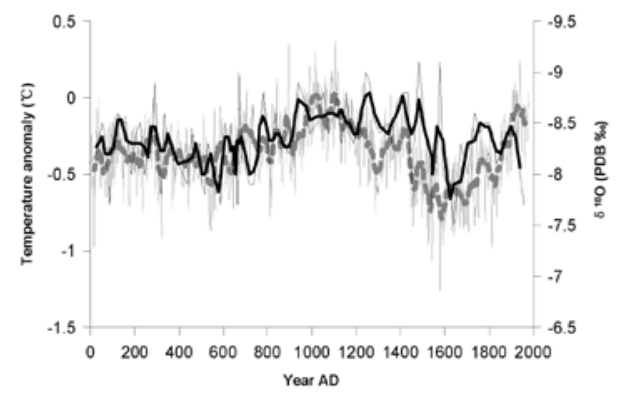

Fig. 6. Comparison of the oxygen isotope of stalagmite from Beijing Shihua Cave (black, thick solid line: 3-point running mean) with the $\mathrm{NH}$ temperature over the last 2000 years reconstructed by Moberg et al., 2005 (grey, thick dashed line: 31-year running mean).

the stalagmite oxygen isotope ratios from Monsoon China may be responding to large-scale temperature changes. What needs to be indicated is that the stalagmite from Beijing Shihua Cave and its isotope data and layer thickness data are independent and different (i.e. unique) from another stalagmite from the same cave (Tan et al., 2003) that has been included in the Moberg et al. series (2005). Therefore, the relationship shown in figure 6 is not a circular argument.

Similarly, Mangini et al. (2005) calibrated a stalagmite oxygen isotope sequence from the Central Alps with the same NH temperature records (Moberg et al. 2005), which also indicates that the lighter oxygen isotope ratios in the stalagmite correspond to higher temperatures.

After temperature calibration for one of these records shown in figure 2 , it is subsequently noted that it was rather warm in north China (e.g. a $\& b$ in Fig.2) but not so warm in the south (e.g. c \& d in Fig.2) during the Medieval Epoch (around 1000 to 1400 AD, as indicated by the shadow band in Fig.2).

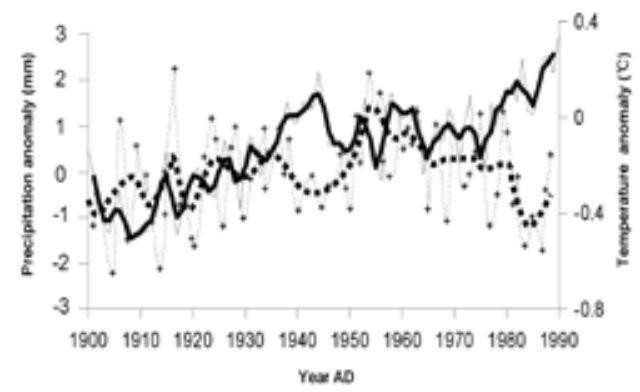

Fig. 5. Comparison of the $\mathrm{NH}$ average precipitation (dashed line, after Dai et al., 1997, see text for details) with the $\mathrm{NH}$ average temperature (solid line). Thick lines are 3-year running mean.

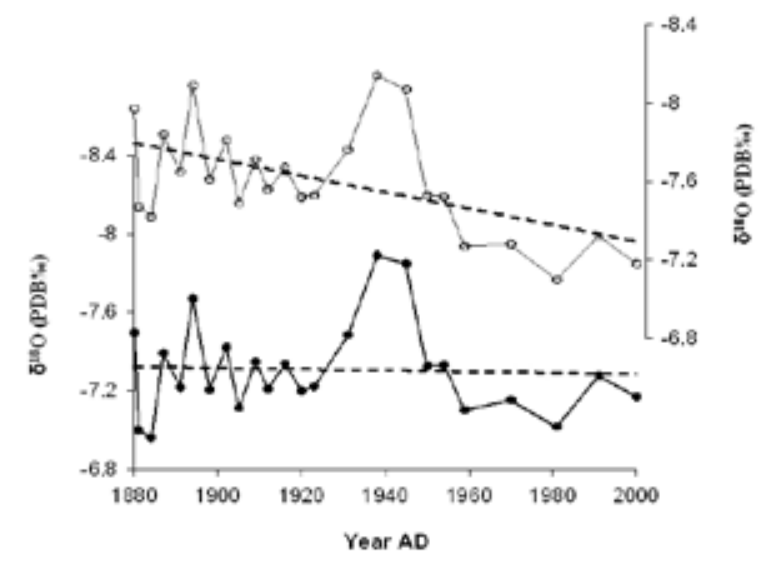

Fig. 7. The stalagmite $\delta 180$ from Dongge Cave ( Wang et al., 2005) since $1880 \mathrm{AD}$ with the linear trend to heavier (upper curve) and detrended (lower curve)

\section{SIGNAL CALIBRATION}

Taking into account all the records listed above, the author further calibrates the stalagmite oxygen isotope series from Dongge Cave (Wang et al., 2005; c in Fig. 1 \& 2, data from: http://www.sciencemag. org/cgi/data/308/5723/854/DC1/1) with largescale observed temperature data of southwest China provided by Wang et al. (1998b). For the purpose of investigating the climate over the last millennium, only the last part of the stalagmite oxygen isotope series is used, which contains 249 measured 8180 data (from 999 to $2000 \mathrm{AD}$ ) and already age-controlled by nine U-Th dates. The errors of isotope measurements have already been described in Wang et al. 2005. The calibration procedure is composed of three steps:

1) removing the linear trend to heavier values (upper curve in Fig.7), which corresponds to the decrease in summer monsoon (Guo et al., 2004) driven by the reduced insolation, using the linear function $\mathrm{Y}=$ $0.00387 * \mathrm{X}-15.054$

2) a simple arithmetic temporally-interpolated annual average was used to make a synthetic annual $\delta 180$ time series for being reasonably calculated with 


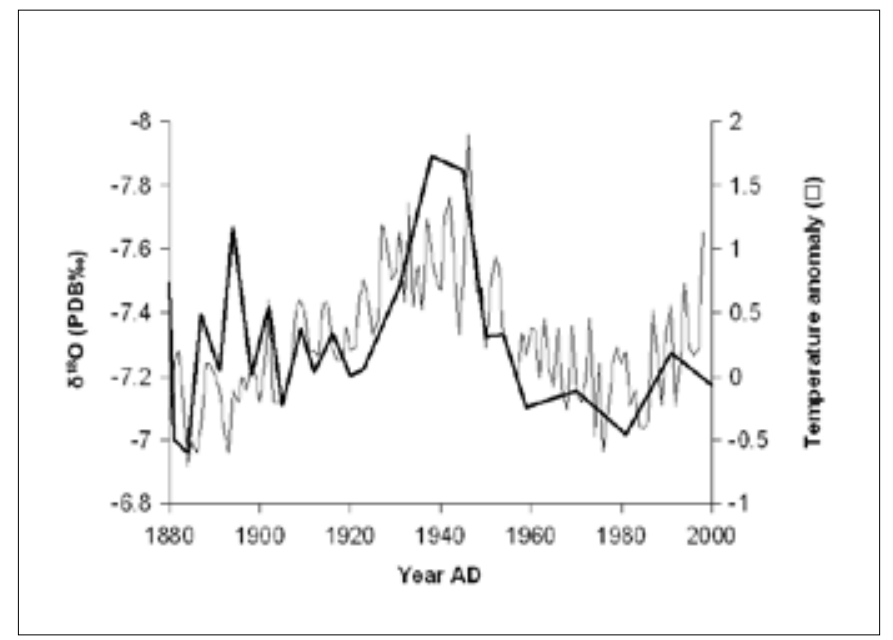

Fig. 8. Relationship of the stalagmite oxygen isotope record from Dongge Cave (thick line, Wang et al., 2005), from which the trend to heavier values has been removed using a linear function (see Fig.7 and text for details), and the Southwest regional temperature (thin line, Wang et al., 1998b).

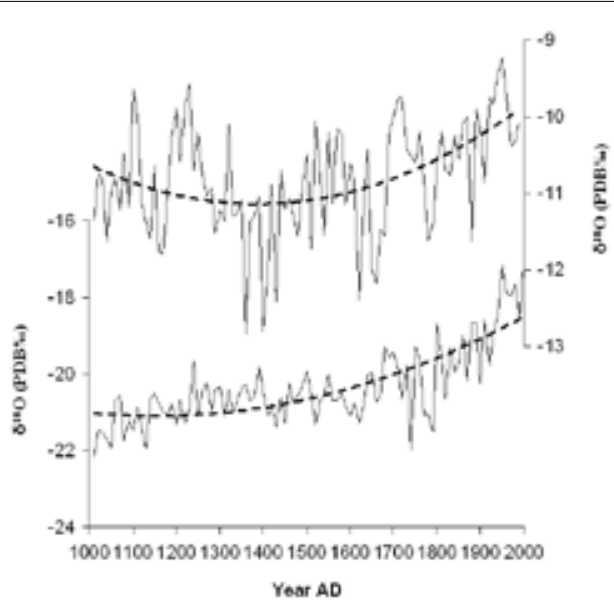

Fig. 10. Comparison between $\delta 180$ in Dunde ice core (upper curve) and in Dasuopu ice core (lower curve). Thick dashed lines are 2ndorder polynomial fits (data from website: http://wdc.cricyt.edu.ar/paleo/ icecore.html).

the observed annual data;

3) calibrating the new oxygen isotope series (lower curve in Fig. 7 and thick line in Fig. 8) with the southwest regional temperature data (Wang et al., 1998b, thin line in Fig.8). The reconstruction function is $\mathrm{T}=-1.21 \times \mathrm{O}-8.58$, where $\mathrm{T}$ is temperature and $\mathrm{O}$ oxygen isotope; Residual sum of squares $=18.94$, regression sum of squares $=9.07, \mathrm{r}=-0.57$ and $\mathrm{r} 2=0.32$, i.e. about $32 \%$ of the temperature variance can be explained by the new series.

\section{CLIMATIC DIFFERENCES AND SIMILARITIES AMONG REGIONS REVEALED BY MULTI-RECORDS}

After being derived from the correlation between stalagmite oxygen isotope series and the observed climate records, the reconstructed temperature series allows the possibility of comparing the climate pattern in southwest China (lower record in Fig.9) with that in northeast China where the temperature series reconstructed by stalagmite lamina thickness

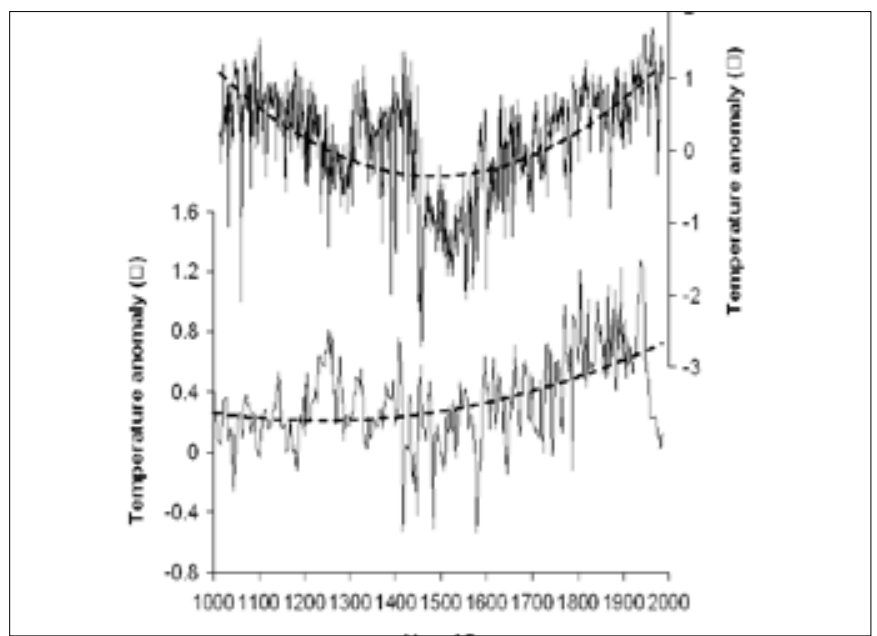

Fig. 9. Comparison of the temperature anomalies derived from stalagmite oxygen isotope from Dongge Cave, southwest China (lower curve, see text for details) with the temperature anomalies derived from stalagmite layer thickness from Shihua Cave, northeast China (upper curve, see text for details). Thick dashed lines are 2ndorder polynomial fits.

already exists (Tan et al., 2003, upper record in Fig.9). However, the absolute magnitude of fluctuation in the two records cannot be compared because the record from Shihua Cave represents summer temperature and the record from Dongge Cave represents annual temperature.

Fig.9 shows that the temperature was high in Beijing both in the medieval period and the 20th century, whereas the temperature was not so high in the medieval period in the Dongge Cave region. Meanwhile, the records show that both areas were colder in the Spörer Minimum epoch (around 1420 to 1570 AD) than in the modern age, being even colder than in the Maunder Minimum epoch (around 1645 to $1715 \mathrm{AD})$.

The difference in climate pattern between north and south China can be further confirmed by millennial temperature records of ice cores from the QinghaiTibetan Plateau. $\delta 180$ of Dunde ice core (upper curve in Fig.10, $\delta 180$ therein has been interpreted as temperature record, Yao et al., 1991) located in the north of the Qinghai-Tibetan Plateau $\left(38^{\circ} 06^{\prime} \mathrm{N}\right.$, $96^{\circ} 25^{\prime} \mathrm{E}, 5325 \mathrm{~m}$ asl, circle 1 in Fig. 1 ) exhibits high average temperature during the early part of the last millennium and is consistent with the MWP. On the contrary, $\delta 180$ of Dasuopu ice core (lower curve in Fig. 10, $\delta 180$ therein has been interpreted as temperature record, Thompson et al., 2000) located in the south of the Qinghai-Tibetan Plateau $\left(28^{\circ} 23^{\prime} \mathrm{N}\right.$, $85^{\circ} 43^{\prime} \mathrm{E}, 7199 \mathrm{~m}$ asl, circle 2 in Fig. 1 ) exhibits rather low average temperature during the early part of the last millennium and is consistent with the pattern of the stalagmite $\delta 180$ from southwest China shown in Fig.9. In addition, a tree ring temperature record from Qilian Mountain, near Dunde ice core also shows high average temperature during the early part of the last millennium (Liu et al., 2005). And an unpublished stalagmite $\delta 180$ record from Wanxiang Cave located at latitude $33^{\circ} 19^{\prime} \mathrm{N}$ also possesses the MWP (Pingzhong Zhang et al.'s data, unpublished). 


\section{DISCUSSIONS}

The oxygen isotope records from stalagmites in Asia have frequently been interpreted as a signature of the strength of the Asian summer monsoon (e.g. Wang et al., 2001; Fleitmann et al., 2003; Yuan et al., 2004; Wang et al., 2005), possessing a common pattern of millennial-scale that was considered to be controlled by orbital insolation. Taken together Fig. 9 and 10 , however, it is clear that there was a distinct difference in climate variation on centennial scale between northeast and southwest China although both regions are located in monsoon Asia. Since the moisture that provides the precipitation on Dasuopu during the summer monsoon season originates in the Indian Ocean (Thompson et al., 2000), it could thus be inferred that the Indian monsoon shaped the climate pattern of decadal-centennial scale for southwest China, whereas the East Asian monsoon plays an important role in northeast China where the temperature variations over the last millennium present a V-shape profile, similar to that of the $\mathrm{NH}$ average. Another direct proof from the coast of India in the northeastern Arabian Sea (Agnihotri et al., 2002) indicated that Indian monsoon was weak within the medieval period compared to the East Asian summer monsoon.

In light of the recent climate study, the Dongge Cave and Xiangshui Cave (c and d in Fig. 1) at present located in the East Asian monsoon area (Ding, 2007), however are both found to be affected by the Indian monsoon during the medieval time, i.e. the Indian summer monsoon affected much larger areas in the medieval time than it does today.

The stalagmite record from Dongge Cave lacks centennial-submillennial scale fluctuations, resulting in a trend towards heavier values over the whole of the Holocene (c in Fig. 2). In contrast, the stalagmite isotope profiles in northeast China possess strong centennial-submillennial scale fluctuations (e.g. a \& b in Fig.2), the linear heavier-trend in the whole Holocene is therefore not as clear as in southwest China.

\section{CONCLUSIONS}

Stalagmite oxygen isotope ratios in China may contain different climate signatures at different time scales: strength of monsoon on millennial-scale that may be driven by orbital insolation, fluctuation of temperature on centennial-submillenial scale that may be driven by solar activity and amount of precipitation on short time scale that may be driven by local or complicated forcing.

It is found that there was a "Medieval Warm Period" (around 1000 to $1400 \mathrm{AD}$ ) in the regions of China where climate is dominated by the East Asian monsoon; whilst no such interval is evident in the regions of China where climate is dominated by the Indian monsoon. The sphere of influence of the Indian monsoon or the East Asian monsoon may be not constant The result achieved in this paper then may allow the possibility of distinguishing the boundary between Indian monsoon and East Asian monsoon regions over the last millennium with increase of climate records, especially stalagmites that are mostly suitable for accurate U/Th dating and/or lamina counting.

\section{ACKNOWLEDGMENTS}

The author thanks Hai Cheng for his help of dating the stalagmites and Yongjin Wang for his data on the net and helpful discussions as well as Shaowu Wang for providing synthetic regional temperature data. Critical reviews by Ian Fairchild and Russell Drysdale are sincerely appreciated. This project was supported by the National Natural Science Foundation of China (grant 90502009), the Ministry of Science and Technology of China (grant 2004CB720206) and the Chinese Academy of Sciences (grant KZCX2-YW316).

\section{REFERENCES}

Agnihotri R., Dutta K., Bhushan R. \& Somayajulu B.L.K., 2002 - Evidence for solar forcing on the Indian monsoon during the last millennium. Earth and Planetary Science Letters, 198: 521-527.

Berger A. L., 1978 - Long-Term variations of Daily Insolation and Quaternary Climatic Changes. Journal of the Atmospheric Sciences, 35: 2362-2367.

Berger A. \& Loutre M.F., 1991 - Insolation values for the climate of the last 10 million years. Quaternary Sciences Reviews, 10: 297-317.

Bradley R.S., Hughes M.K. \& Diaz H.F., 2003 - Climate in Medieval Time. Science, 302 (5644): 404-405.

Briffa K. R., 2000 - Annual climate variability in the Holocene: interpreting the message of ancient trees. Quaternary Sciences Reviews, 19: 87- 105.

Crowley, T. J. \& Lowery T. S., 2000 - How warm was the Medieval Warm Period? AMBIO, 29: 51- 54.

Cruz Jr. F. W., Burns S. J., Karmann I., Sharp W. D., Vuille M., Cardoso A.O., Ferrari J.A., Dias P.L.S. \& Oduvaldo V.J., 2005 - Insolation-driven changes in atmospheric circulation over the past 116,000 years in subtropical Brazil. Nature, 434: 63-66.

Dai A., Fung I.Y. \& Genio A.D.D., 1997 - Surface Observed Global Land Precipitation Variations during 1900-88, Journal of Climate, 10 (11): 2943-2962.

Dansgaard W., 1964 - Stable isotopes in precipitation. Tellus, 16: 436-468.

Ding Y., 2007 - The variability of the Asian Summer Monsoon, J. Meteoro. Soc. Japan, 85B, in press.

Esper J., Edward R. C. \& Schweingruber F. H., 2002 - Low Frequency Signals in Long Tree-Ring Chronologies for Reconstructing Past Temperature Variability. Science, 295: 2250-2253.

Fleitmann D., Burns S. J., Mudelsee M., Neff U., Kramers J., Mangini A. \& Matter A., 2003 - Holocene Forcing of the Indian Monsoon Recorded in a Stalagmite from Southern Oman. Science, 30: 1737-1739.

Frisia S., Borsato A., Preto N. \& McDermott F., 2003 Late Holocene annual growth in three Alpine stalagmites records the influence of solar activity and the North Atlantic Oscillation on winter climate. Earth and Planetary Science Letters, 216: 411-424.

Guo Q., Cai J. \& Shao X., 2004 - Studies on the variations of East-Asian summer monsoon during AD 1873-2000. 
Chinese Journal of Atmospheric Sciences, 28(2): 206215 (in Chinese).

Hafsten U., 1970 - A subdivision of the Late Pleistocene Period on a synchronous basis intended fro global and universal usage. Palaeogeography, Palaeoclimatology, Palaeoecology, 7: 279-296.

Hou J.Z., Tan M., Cheng H. \& Liu T.S., 2003 - Stable isotope records of plant cover change and monsoon variation in the past 2200 years: evidence from laminated stalagmites in Beijing, China. Boreas, 32: 304-313.

Hughes M. K. \& Diaz H.F., 1994 - Was there a 'medieval warm period', and if so, where and when? Climatic Change, 26: 109-142.

Jones, P. D., Briffa K. R., Barnett T. P. \& Tett F. S. B., 1998 - High-resolution paleoclimatic records for the last millennium: Interpretation, integration and comparison with General Circulation Model control run temperatures. The Holocene, 8: 467- 473.

Lamb H.H., 1965 - The early Medieval Warm Epoch and its sequel. Palaeogeography, Palaeoclimatology, Palaeoecology, 1: 13-37.

Lamb, H. H., 1977 - Climate, Present, Past and Future. Methuen, London. 613 p.

Li, H-C., Ku, T-L., Stott, L.D., \& Chen W-J., 1998 - Applications of interannual-resolution stable isotope records of speleothem: Climatic changes in Beijing and Tianjin, China during the past 500 years - the $\delta^{18} \mathrm{O}$ record. Science in China (Series D), 41: 362-368.

Li W-X., Lundberg J., Dickin A. P., Ford D.C., Schwarcz H.P., McNutt R. \& Williams D. 1989 - High-precision mass-spectrometric uranium-series dating of cave deposits and implications for palaeoclimate studies. Nature, 339: 534- 536.

Liu X., Qin D., Shao X., Chen T. \& Ren J., 2005 Temperature variations recovered from tree-rings in the middle Qilian Mountain over the last millennium. Science in China (Ser. D Earth Sciences), 48 (4): 521-529.

Mangini A., Spotl C. \& Verdes P., 2005 - Reconstruction of temperature in the Central Alps during the past 2000 yr from a $\delta^{18} \mathrm{O}$ stalagmite record. Earth and Planetary Science Letters, 235: 741-751.

Mann, M. E., R. S. Bradley \& M. K. Hughes, 1999 - Northern hemisphere temperature during the past millennium: inferences, uncertainties, and limitations. Geophysical Research Letters, 26: 759- 762.

Mann M.E. \& Jones P.D., 2003 - Global Surface Temperatures over the Past Two Millennia. Geophysical Research Letters, 30: 1820.

Moberg A., Sonechkin D.M., Holmgren K., Datsenko N.M. \& Karle'n W., 2005 - Highly variable Northern Hemisphere temperatures reconstructed from low- and high-resolution proxy data. Nature, 433: 613-617.

Neff U., Burns S. J., Mangini A., Mudelsee M., Fleitmann D. \& Matter A., 2001 - Strong coherence between solar variability and the monsoon in Oman between 9 and 6 kyr ago. Nature, 411: 290-293.

Paulsen D. E., Li H.-C. \& Ku T.-L., 2003 - Climate variability in central China over the last 1270 years revealed by high-resolution stalagmite records. Quaternary Science Reviews, 22: 691-701.
Proctor C.J., Baker A., Barnes W.L. \& Gilmour M.A., 2000 - A thousand year speleothem proxy record of North Atlantic climate from Scotland. Climate Dynamics, 16: 815-820.

Shen C., Edwards R.L., , Cheng H., Dorale J. A., Thomas R. B., Bradley M. S., Weinstein S. E. \& Edmonds H. N., 2002 - Uranium and thorium isotopic and concentration measurements by magnetic sector inductively coupled plasma mass spectrometry. Chemical Geology, 185(34): $165-178$.

Tan M., Liu D., Zhong H., Qin X., Li H.-C., Zhao S., Li T., Lü J., \& Lu X., 1998 - Preliminary study on climatic signals of stable isotopes from Holocene speleothems under monsoon condition. Chinese Science Bulletin, 43: 506-509.

Tan M., Liu T., Hou J., Qin X., Zhang H. \& Li T., 2003 - Cyclic rapid warming on centennial-scale revealed by a 2650-year stalagmite record of warm season temperature. Geophysical Research Letters, 30 (12): 1617-1620.

Tan M. \& Cai B., 2005 - Preliminary Calibration of Stalagmite Oxygen Isotopes from Eastern Monsoon China with Northern Hemisphere Temperatures. PAGES News, 13 (2): 16-17.

Thompson L.G., Yao T., Thompson E.M., Davis, M.E., Henderson K.A. \& Lin P.-N., 2000 - A high-resolution millennial record of the south Asian Monsoon from Himalayan ice cores. Science, 289: 1916-1919.

Wang S., Ye J. \& Gong D., 1998a - Climate in China during the Little Ice Age. Quaternary Sciences, 18 (1): 54-64 (in Chinese with English abstract).

Wang S. W., Ye J. L., Gong D. Y. \& Zhu J. H., 1998b - Construction of mean annual temperature series for the last one hundred years in China. Quart. J. Applied Meteo., 9 (4): 392-401 (in Chinese with English abstract).

Wang Y., Cheng H., Edwards R.L., An Z., Wu J., Shen C. \& Dorale J.A., 2001 - A High-Resolution Absolute-Dated Late Pleistocene Monsoon Record from Hulu Cave, China. Science, 294: 2345 - 2348.

Wang Y., Cheng H., Edwards R. L., He Y., Kong X. An Z., Wu J., Kelly M.J., Dykoski C.A. \& Li X., 2005 - The Holocene Asian Monsoon: Links to Solar Changes and North Atlantic Climate. Science, 308: 854 - 857.

Yao T., Xie Z., Wu X. \& Thompson L.G., 1991 - Climatic change since the Little Ice Age recorded in the Dunde ice cap. Science in China (Series D), 34: 760-767.

Yuan D., Cheng H., Edwards R. L., Dykoski C. A., Kelly M. J., Zhang M., Qing J., Lin Y., Wang Y., Wu J., Dorale J. A., An Z. \& Cai Y., 2004 - Timing, Duration, and Transitions of the Last Interglacial Asian Monsoon, Science, 304: $575-578$.

Zhang D., 1993 - A study on the Medieval Warm Period in China. Quaternary Sciences, 13 (1): 7-15 (in Chinese with English abstract).

Zhang M., Yuan D., Lin Y., Qin J., Li B., Cheng H. \& Edwards R. L., 2004 - A 6000-year high-resolution climatic record from a stalagmite in Xiangshui Cave, Guilin, China. The Holocene, 14: 697-702. 